Primljeno: 16.01.2013.

Izvorni znanstveni rad

UDK: 316.614-053.4:371.382

\title{
ZNAČAJ IGRE U SOCIJALIZACIJI DJECE PREDŠKOLSKOG UZRASTA
}

Mr. sc. Alisa Mahmutović

JU za odgoj i obrazovanje djece

predškolskog uzrasta Srebrenik, $\mathrm{BiH}$

e-mail:mahmutovicalisa@gmail.com

\section{SAŽETAK}

Kako je igra u socijalizaciji predškolske djece jedan od značajnih faktora, usudit ćemo se reći skoro pa ključni faktor, odlučili smo da u ovom istraživanju posvetiti pažnju dječijoj igri. U ovom radu nastojali smo teorijski što detaljnije prikazati značaj igre u socijalizaciji predškolske djece, kao i to kako igra može doprinijeti kvalitetnoj i zdravoj socijalizaciji predškolske djece.

Opšti cilj ovog istraživanja je ispitati ulogu igre u socijalizaciji djece predškolskog uzrasta. Ovim istraživanjem se želi otkriti koliku su djece predškolskog uzrasta sposobna da samostalno organizuju igru, da prihvate temu igre i uloge u igri koje im dodjeljuju druga djeca, da usklade svoje ideje sa idejama svojih vršnjaka i da aktivno učestvuju u igri.

Istraživanjem je obuhvaćeno 20 djece predškolskog uzrasta. Rezultati dobiveni ovim istraživanjem upućuju na ogroman značaj igre u sodijalizaciji djece predškolskog uzrasta.

Ključne riječi: socijalizacija, predškolska djeca, igra.

\section{UVOD}

Kroz ovaj rad nastoji se ukazati na značaj koji igra ima u socijalizaciji predškolske djece, te kako proces igre i kontakti koje djeca ostvaruju sa vršnjacima u toku igre utiču na njihov razvoj. Poznato je da djeca kroz igru ostvaruju svoje prve kontakte i da na taj način postepeno stupaju u svijet odraslih. Djeca kroz igru oponašaju odrasle, njihove postupke i na taj način se uživljavaju u svijet odraslih. Igrom i igrovnim aktivnostima djeca simuliraju stvarnost, a zapravo u tim simulacijama ostvaruju značajan dio svog realnog života (Suzić, 2006). Igra je zapravo dječija realnost. Igra predstavlja najznača- 
jniji put razvoja ličnosti djeteta, njegovu pripreme za odrastanje i kroz igru, ako je ona pravilno vođena uz pomoć roditelja ili odgajatelja, dijete uči kako da uspostavlja zdrave socijelne kontakte, da se ponaša na adekvatan i ispravan način u određenim situacijama i da izbjegava konflikte u kontaktima sa drugom djece i da ako dođe do konflikata bude spremno i zna da riješi konflikt na miran način. Igra je za predškolsko dijete i najprirodniji i najlakši način učenja, zbog toga što je ono u igri motivisano i emotivno angažovano. „Savremeni psiholozi tumače igru kao specifčnu formu učenja, koja treba da dobije dominantno i vodeće mijesto u predškolskom periodu“ (Mitrović, 1981, 53). U psihologiji ne postoji jedinstveno mišljenje o tome od kojeg uzrasta ličnost može da se uključe u kolektiv (Grupa autora, 1982). Istraživanja pokazuju da među djecom od 6 i 7 godina, postoje svi oblici primarnog kolektiva, ali su izraženi u specifičnom obliku. Predškolska djeca, u procesu igre, neprestano prihvataju određene uloge u međusobnim odnosima, ona postavljaju opšte ciljeve aktivnosti i trude se da ih zajedno ostvare. Igrajući se dijete spontano aktivira svoju kogniciju, pušta mašti na volju, oslobađa svoje emocije, razvija socijalne odnose, kreće se i djeluje (Suzić, 2006). Posmatranjem djece i praćenjem njihovog razvoja vaspitač može pozitivno uticati na njihov razvoj tako što će planirati i izvoditi vaspitno-obrazovni rad nastavljajući igre u „zoni narednog razvoja“ (Vigotski, 1996, 29) stvarajući uslove za stvarno napredovanje djetate nastavljajući onaj nivo na kome se dijete već nalazi.

\section{VRSTE IGARA I IGROVNIH AKTIVNOSTI}

Dječija igra ima mnogostruko značenje. Igra pomaže djetetu da upozna vrijednost raznih moralnih normi. U kontaktu s drugom djecom razvija se saznanje o značenju poštenja, istinoljubivosti i hrabrosti. U igri s vršnjacima dijete stiče navike pozitivnog ponašanja koje ne bi steklo da se kreće isključivo u društvu odraslih. Imitiranjem ponašanja drugih ljudi moguće je usvajati nove oblike ponašanja koje iskazuje neki promatrani model. Dječije igre se razlikuju po sadržaju, po broju učesnika, po mjestu izvođenja, po načinu organizacije i po mnogim drugim karakteristikama. U literaturi se navode različite klasifikacije dječijih igara. Emil Kamenov (1997) navodi četiri vrste dječijih igara:

- Funkcionalne igre

- $\quad$ Igre mašte ili igre uloga

- Igre sa gotovim pravilima

- Konstruktorske igre

Funkcionalne igre dijete izvodi zato što je ovladalo funkcijama svoga tijela, igračaka ili sredstava oko sebe. Ovdje se više radi o igrolikim aktivnostima nego o stvarnim igrama. Kamenov navodi više vrsta ovih aktivnosti: senzorne aktivnosti sopstvenim organima, igre posvećene rukovanju materijalom, pokretne igre uz korištenje rekvizita, igra glasovima, slovima ili riječima.

Igre mašte ili igre uloga se oslonjaju na slobodnu volju djeteta, na skolonost dje- 
teta da u mašti stvarnost prikaže na sebi svojstven način. Ove igre prepoznajemo u više formi: imitacija i podražavanje, igre iluzije, dramske igre, fiksacije i sl. U okviru ovih igara Kamenov razlikuje sledeće forme: oponašanje postupaka, simbolička imitacija, simbolička igra uloga sa sižeom, dramske igre uloga.

Igre s gotovim pravilima razlikujemo od igara u kojima se pravila konstruišu $\mathrm{u}$ toku igranja. Često se igrovne aktivnosti u kojima nema pravila pretvaraju u igru s pravilima zato što se pravila konstruišu tokom aktivnosti. Najveći broj igara ima gotova pravila koja se iz generacije u generacije prenose na pokoljenja u datim kulturama. Igre sa gotovim pravilima su posebno pogodne za pedagoške uticaj koje vaspitači ostvaruju u radu sa predškolskom djecom.

Konstruktorske igre obuhvataju aktivnosti u kojima dijete oblikuje materijal, slaže, gradi ili raspoređuje kako bi postiglo određeni cilj. Rezultat ove aktivnosti ne mora biti nešto funkcionalno, to može biti estetski ili metaforički učinak.Postoji više oblika u kojima se javljaju konstruktorske igre. To su: pronalaženje kombinacija nastalih namjernim rukovanjem materijalom, oblikovanje, redanje materijala, grafičko predstavljanje, građenje gotovim materijalom i organizovanje materijala i utilitarne konstrukcije.

Drugačiju klasifikaciju igara daje Šoljan (1976). On razlikuje igre sposobnosti, igre šanse, igre realnosti i igre mašte.

Igre sposobnosti baziraju se na sposobnostima igrača. Za ove igre je neophodno da svi sudionici imaju adekvatne sposobnosti. Takva igra je npr. fudbal.

Igre šansi se baziraju na sreći igrača da uz djelovanje slučaja ostvari željeni cilj. Ove igre ne traže posebne sposobnosti sudionika i na početku svi imaju jednake šanse. Prednost ovih igara je što djeci daju jednake šanse i ne razvijaju osjećaj inferiornosti.

Igre realnosti najbliže su predškolskom uzrastu. To su igre i igrovne aktivnosti u kojima djeca oponašaju situacije iz realnog života.

Igre mašte su djeci najdraže. Ove igre su bliže igrovnim aktivnostima nego strogo definisanim igrama.

\section{PROCES SOCIJALIZACIJE DJECE KROZ IGRU}

Igrom i igrovnim aktivnostima djeca simuliraju stvarnost, a zapravo u tim simulacijama ostvaruju značajan dio svog realnog života. Dijete simuliranjem proučava realnost, pokušava da joj se približi na svoj bezazlen virtualni način. Putem igre ili igrovnim aktivnostima djeca testiraju svoje mogućnosti , uspostavljaju odonose sa drugom djecom i odrasilma, odnosno stvaraju modele u kojima intezivno sjedinjuju realnost i maštu (Suzić, 2006). Socijalizacija je složen proces učenja kojim kroz interakciju sa svojom društvenom okolinom usvajamo znanja, stavove, vrijednosti i ponašanja neophodna za sudjelovanje u životu društva. To je spona između pojedinca i društva, bez koje ne bi bilo ni jednog ni drugog. Jedan od najvažnijih učinaka socijalizacije jeste razvoj ličnosti kao relativno stabilne složevine načina razmišljanja, osjećanja i ponašanja pojedinca. (Fanuko, 1997). Uspješna socijalizacija znači intenzivno razvijanje sposobnosti djeteta u predškolskom razdoblju. Ni u jednom kasnijem razdoblju dijete nije više tako plastično 
(prijemčivo), a njegove se sposobnosti ne mogu nikada više tako aktivirati kao u toj dobi. Primarna socijalizacija se odvija u predškolskoj dobi, odnosno od rođenja djeteta pa do polaska djeteta u školu kroz kontakte sa odraslima a posebno sa vršnjacima. Vršnjaci omogućavaju maloj djeci iskustvo učenja koje ne mogu steći na drugi način. Budući da vršnjaci komuniciraju ravnopravno, oni moraju preuzeti odgovornost za održavanje razgovora, za suradnju, te postavljanje ciljeva u igri. Mildred Parten (1932, prema Berk, 2007) zaključila je da se socijalni razvoj odvija u slijedu od 3 koraka. Počinje sa nesocijalnom aktivnosti - neangažiranjem, promatračkom aktivnosti i samostalnom igrom. Nakon toga prelazi se u paralelnu igru, Pri čemu se druga djeca igraju pored druge djece, ali ne pokušavaju uticati na njihovo ponašanje. Na najvišoj su razini dva oblika stvarne socijalne interakcije. Jedan je asocijativna igra, kod koje su djeca uključena u odvojene aktivnosti, ali razmjenjuju igračke i uzajamno komentiraju ponašanje. Druga je suradnička igra, to je napredniji oblik interakcije u kojoj su djeca usmjerena prema zajedničkom cilju, poput glumljenja u igri ili gradnje dvorca od pijeska (Berk, 2007). Gotovo svi istraživači koji su se bavili opisivanjem igara djece predškolskog uzrasta slažu se u tome da se suština dječije igre sastoji u igranju uloga. Glavnu komponentu igre uopšte, čini uloga koju dijete prihvata. Sve ostale komponente igre određene su ulogom i radnjama koje su sa njom povezane. Da bi se ostvarila npr. uloga putnika i prodavača karata, listići papira postaju novac i karte. Odnosi između djece koji se uspostavljaju u toku igre takođe zavise od uloga. Za samu djecu koja učestvuju u igri, ako sudimo po njihovom ponašanju, najvažnija stvar je da ispune ulogu koju su preuzela. To se vidi i po tome s kakvom se marljivošću i pedantnošću ona odnose prema izvršenju radnji koje nameće prihvaćena uloga (Eljkonjin, 1978). Kroz sam proces igre djeca dakle uče različite uloge i na taj način se „pripremaju“ za stvarni život.

\section{METODOLOGIJA ISTRAŽIVANJA}

\section{Ciljevi istraživanja}

Osnovni cilj ovog neeksperimentalnog empirijskog istraživanja je ispitati, analizirati i interpretirati ulogu igre u socijalizaciji djece predškolskog uzrasta. Ovim istraživanjem se želi otkriti koliku su djece predškolskog uzrasta sposobna da samostalno organizuju igru, da prihvate temu igre i da se adaptiraju i prihvate uloge u igri koje im dodjeljuju druga djeca, da usklade svoje zamisli i ideje sa idejama svojih vršnjaka, da aktivno učestvuju u igri te da uspostave određeni tip odnosa sa svojim vršnjacima.

\section{Problemi istraživanja}

Sukladno navedenim ciljevima definisani su sljedeći problemi istraživanja: 
1. Ispitati da li djeca predškolskog uzrasta mogu samostalno da organizuju igru.

2. Ispitati da li djeca predškolskog uzrasta mogu da prihvate uloge koju im druga djeca dodjeljuju u toku igre.

3. Ispitati da li su djeca predškolskog uzrasta sposobna da učestvuju u zajedničkoj igri i da poštuju pravila igre.

\section{Hipoteze}

Sukladno rezultatima dosadašnjih istraživanja postavili smo sledeće hipoteze istraživanja:

1. Pretpostavljamo da djeca predškolskog uzrasta mogu samostalno da organizuju igru.

2. Pretpostavljamo da djeca predškolskog uzrasta mogu da prihvate uloge koje im druga djeca dodjeljuju u toku igre.

3. Pretpostavljamo da su djeca predškolskog uzrasta sposobna da učestvuju u zajedničkoj igri i da poštuju pravila igre.

\section{UZORAK ISTRAŽIVANJA}

Istraživanje je obuhvatilo uzorak od 20 polaznika JU za odgoj i obrazovanje djece predškolskog uzrasta Srebrenik. Starosna dob ispitanika bila je 6 godina. Sudionici su odabrani za sudjelovanje u ovom istraživanju neslučajnim namjenskim uzorkovanjem kako bi se zadovoljile potrebne karekteristike uzorka (dob), koje su značajne za predmet ovog istraživanja.

\section{METODI I MJERNI INSTRUMENTI}

U svrhu ispitivanja hipoteza kao osnovni metod istraživanja primjenjena je metoda posmatranje neeksperimentalnog empirijskog istraživanja. Pored ove metoda korišteni su i mjerni instrumenti u kojima su bilježeni podaci dobivani za vrijeme posmatranja (protokol posmatranja i ček lista). Ovi mjerni instrumenti konstruisani su isključivo za svrhu ovog istraživanja, a podaci prikupljeni ovim mjernim instrumentima korišteni su za statističku obradu podataka. Protokol posmatranja ima oblik tabele a sadrži rubrike predviđene za naziv projekta (istraživanja), ima i prezime istraživača, vrijeme i mjesto posmatranja, lice koje se posmatra, aktivnosti koje se posmatraju, ono što ce se posmatrati u odnosu na aktivnosti posmatranja, materijal korišeten u igri, interpretacija napomene i sisitematizacija. Ček-lista je sačinjena od nekoliko tvrdnji koje su značajne za ovo istraživanje. Rezultati dobiveni u ovom istraživanju tretirani su kvantitativnom i kvalitativnom analizom. 


\section{POSTUPAK}

Istraživanje je vršeno u JU za odgoj i obrazovanje djece predškolskog uzrasta Srebrenik. Prije nego smo pristupili prikupljanju podataka obavljene su pripreme za istraživanje. Pripreme su se sastojale u razgovoru sa ravnateljom ustanove u kojoj je obavljeno istraživanje, razgovor sa roditeljima i dobijanje saglasnosti od roditelja čija su djeca bili sudionici istraživanja budući da se radi o malodobnim sudionicim. Ove pripreme su obuhvatile i razgovor sa odgajateljima koji su pomagali u realizaciji ovog istraživanja. Sam proces posmatranja dječije igre i prikupljanja podataka vršen je u period od deset dana. Proces posmatranja igre i prikupljanja podataka vršen je uz pomoć odgajatelja. Naime, odgajatelji su u toku procesa prikupljanja podataka učestvovali u organizaciji i usmjeravanju igrovnih aktivnosti, kao i u samom procesu posmatranja dječije igre. U procesu prikupljanja podataka vršeno je posmatranje svakog djeteta u grupnoj igri, kao i pojedinačen aktivnosti svakog djeteta. Za svako dijete je postojao odvojeni protokol posmatranja i ček lista u koje su bilježeni specifični oblici ponašanja svakog djeteta u toku igrovnih aktivnosti.

\section{REZULTATI}

U ovom poglavlju analizirani su rezultati dobiveni posmatranjem djece u procesu igre koji su bilježeni u protokolu posmatranja i ček listi. Prikaz rezultata izvršen je u nekoliko etapa, pa su tako rezultati prikazani i kvalitativno i kvantitativno.

\section{KVALITATIVNA ANALIZA}

Rezultati ovog istraživanja pokazuju da među djecom predškolskog uzrasta postoje svi znaci primarnog kolektiva, ali su izraženi u drugačijem, nešto specifičnijem obliku. Rezultati dobiveni ovim istraživanjem pokazuju da u procesu igre predškolska djeca prihvataju uloge u međusobnim odnosima, sami postavljaju ciljeve aktivnosti (igre) i nastoje da poštuju pravila i da zajednički ostvare ciljeve aktivnosti. Među djecom se pojavljuju različiti odnosi različitog stepena složenosti u procesu igre. Neka djeca preuzimaju potpunu inicijatovu gušeći inicijative svojih vršnjaka, dok druga djeca ne ispoljavaju cilj da budu vođe u igri ali nisu ni pasivna, a neka djeca se ponašaju potpuno pasivno i inferiorno u procesu igre. Takođe pojavljuju se i ona djeca koja prihvataju potpuno podređenu ulogu u procesu igre i prepuštaju se da budu vođena od strane druge djece i prihvataju sve što od njih zahtjeva grupa ili vođa. Rezultati posmatranja u ovim istraživanju pokazuju da na osnovu ponašanja djece, u procesu igre, prema samoj aktivnosti kao i prema ostalim učesnicima aktivnosti, djeca se mogu podjeliti u pet grupa. Svaku od tih grupa karakteriše određeni tip ponašanja i odnosa u grupi (dominantnost - potčinjenost).

Grupa A: u ovu skupinu ubrajaju se djeca koja poduzimaju inicijativu za igru i pokazuju najbolje organizatorske sposobnosti. Oni dijele uloge, predlažu igru i vrstu 
igre, upućuju ostalu djecu šta da rade, pomažu uputama u pripremanju mjesta za igru, ali malo sami rade na pripremanju (ponašaju se kao „šefovi“), u toku same igre nameću svoje ideje, zamisli i pravila a ne žele da prihvate i da se prilagode idejama ostale djece.

Grupa B: ovu grupu čine djeca koja su aktivna u igri, samostalno predlažu ideje ali i prihvataju ideje druge djece. Ova djeca raspoređuju uloge drugoj djeci ali prihvataju i uloge koje se njima dodjeljuju. Aktivno pripremaju mjesto za igru, koriste svoje znanje i sposobnosti te uvažavaju ostalu djecu i svoje aktivosti redovno usklađuju sa aktivnostima ostalih učesnika.

Grupa C: u ovu grupu svrstavaju se djeca koja su bila srednje aktivna u igri i koja su češće prihvatala pravila i ideje druge djece, kao i uloge u igri, koristila su svoja znanja u pripremanju mjesta za igru kao i prijedloge druge djece, te aktivno učestvuju u pripremanju mjesta za igru i usklađivali su svoje ideje sa idejama drugih.

Grupa D: u ovoj grupi su djeca koja su se igrala samo prihvaćajući ideje, uloge i prijedloge druge djece, za sve pripreme dosljedno su slijedili upute i sugestije vršnjaka, nisu davali nikakve prijedloge u odnosu na sadržaj igre, a aktivnosti su usaglašavali sa prijedlozima vršnjaka, ali se to uglavnom odnosilo na to da su oni izvršavali ono što su drugi predlagali, obično aktivnija djeca u igri. U samom procesu igre ova djeca su bila djelimično pasivna i nezainteresovana.

Grupa E: u ovoj grupi su djeca koja su rijetko ili skoro nikako učestvovala u igri s ostalom djecom, s teškoćom su se uključivala u igru, čak kada je za igru bilo sve spremno i kada su ostala djeca sve predložila i pripremila. Čak i kada su se uključivala u igru ova djeca su sve donosila (igračke i igrajući materijal) isključivo po sugestijama i uputama svojih vršnjaka. Tokom cijele igre izvršavala su i slijedila ono sto su im namatela druga djeca. Obično su bili potčinjeni odlukama i idejama drugih i bili su pasivni u toku igrovna aktivnosti.

Procentualno raspored djece po grupama je bio sledeći: u grupi A bilo je 3 djece, u grupi B bilo je 5 djece, u grupi C bilo je 7 djece, u grupi D bilo je 4 djece i u grupi E bilo je 1 dijete.

Odnosi između izvedenih grupa bili su različiti. U toku posmatranja primjećen je različit stepen rukovođenja i potčinjavanja iste djece u kontaktu i kombinaciji sa djecom iz različitih grupa. Kada su djeca iz grupe A stupala u igrovne aktivnosti sa djecim iz iste grupe ili iz grupe B nisu mogla previše doći do izražaja u kao dominani jer su i ostali učesnici aktivnosti pokazivali slične ambicije, tako da su se tu morali „boriti“ za dominantnu ulogu i nikada u potpunosti nisu uspijeveli da nametnu svoje rukovodstvo i svoja pravila i tempo igre. Slika se mijenjala kada su djeca iz grupe A učestvovala u igri sa djecom iz grupa C, D i E jer su tu djeca iz grupa A i B uspijevala da nametnu svoje ideje, pravila i dominantnu ulogu i kontrolu nad igrom. Grupa C je mogla da ispoljava rukovođenje u nekim slučajevima kada su se djeca iz te skupine igrala s djecom iz grupe D i E, dok su ova djeca u odnosima sa djecim iz skupine A i B pokazivala skor pa potpunu potčinjenost njihovim idejama i rukovodstvu. Djeca iz grupa D i E skoro uvijek su imala potčinjenu ulogu kada su stupali u igru sa djecom iz grupa A, B i C a sa djecom iz ove dvije grupe imali su ravropravne uloge iako je takva igra bila rijetka jer ova djeca nisu bila u stanju da smostalno usposatave proces igre i da ga dovedu do kraja. Tokom posmatranja uočila sam da se tipovi dječijeg udruživanja u toku igrovnih aktivnosti mogu imati 
pozitivne i negativne efekte na vaspitanje/socijalizaciju ispravnih međusobnih odnosa među djecom. Naime, djece koja su potpuno dominantna i imaju potpuno rukovodeću ulogu imaju tendenciju da „štetno“ utiču na sebe. Štetno utiču na sebe tako sto sebi onemogućavaju da razviju sposobnosti prihvatanja drugih, njihovih ideja i da se usklađuju s njima. Takođe i kod djece koja su stalno potčinjena i prepuštaju se takvoj ulozi guši se samostalnost, aktivnost i stvaralaštvo i kreativnost. Najpovoljniji uticaj stvaraju djeca koja se udružuju na temelju djelimičnog rukovođenja jer oni omogućavaju sebi da istaknu svoje rukovodeće sposobnosti, da iskoriste svoje ideje, znanja i vještine a takođe omogućeno je i drugoj djeci da istaknu svoje ideje, te su sposobni da svoje ideje usklađuju sa idejama drugih. Tako se kod djece razvija osjećaj prihvatanja i uvažavanja drugih i drugačijih.

Rezultati su pokazali da djeca u toku igre doživljavaju različite kontakte sa svojim vršnjacima što je na njih uticalo na različite načine. Nekada su djeca uspijavala da se oko igre dogovore sa svojim vršnjacima ili da vođe nametnu ostaloj djeci pravila koja oni žele, bez konflikata, a nekada su djeca dolazila u sukob sa drugom djecom jer neka djeca pokušavala da nametnu svoja pravila i da se istaknu kao vođe, ali su im se pojedina djeca suprotstavljala ili su i sami željeli da preuzmu ulogu vođe, te je u takvim situacijama dolazilo do konflikata. Djeca nisu uvijek bila u stanju da samostalno riješe nastali konflikt, pa se povremeno igra završavala i prije nego je i počela ili se vaspitači morali uključili kako bi riješili konflikt.

\section{KVANTITATIVNA ANALIZA}

Kako su pokazali rezultati istraživanja neka djeca mogu samostalno da organizuju igru i da postavljaju pravila igre kao i da se nemeću kao vođe. $40 \%$ djece je moglo samostalno da organizuje igru i da usmjerava tok igre, ali od toga $15 \%$ (grupa A) djece se nametalo kao vođe i „autoritet“ te nisu prihvatali ideje i prijedloge druge djece, 25\% (grupa B) djece je moglo da organizuje i usmjeri igru ali je pri tome uvažavalo i ideje i prijedloge druge djece te se nisu isključivo nametali kao vođe, nego su više bili skloni kompromisnim riješenjima. Djece koja su učestvovala u organizaciji igre, ali uz vodstvo i uputstva druge djece, koristeći sva svoja znanja i vještine ali ne ističući se kao vođe bilo je 35\% (grupa C). Djeca koja su pokorno samo slijedila uputstva, pravila i želje svojih vršnjaka i samo na taj način učestvovala u procesu igre činila su 20\% (grupa D) uzorka. I na kraju svega 5\% (grupa E) uzorka činila su ona djeca (u ovom slučaju samo jedan ispitanik) koji su bili pasivni u igri ili su u potpunosti bili isključeni iz procesa igre. Oni se izbjegavali igru s ostalom djecom a i kada bi pristupili igri isključivo bi radili samo ono što od njih zahtijevaju drugi akteri u igri. Izloženi rezultati su prikazani grafički. 
Grafika br.1 Procentualni prikaz broja djece u svakoj od grupa $(A, B, C, D, E)$

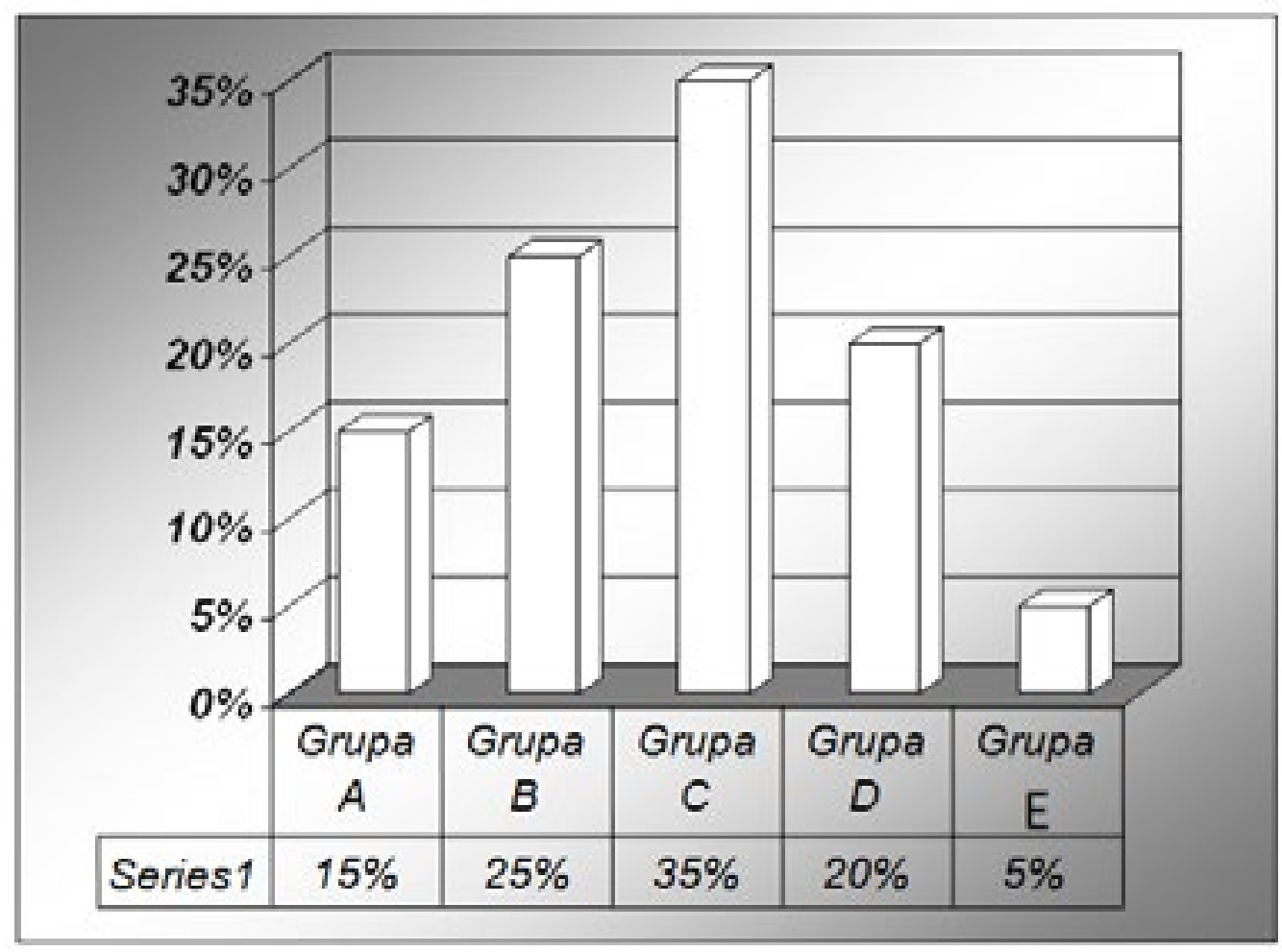

Iz grafičkog prikaza vidi se da su u predškolskom kolektivu kod djece istog uzrasta zastupljeni različiti oblici socijalnog ponašanja, od rukovođenja do potčinjavanja.

\section{REZULTATI ZABILJEŽENI U ČEK LISTI}

U ovom dijelu analizirani su rezultati dobiveni u ček listi koji su obrađeni statistički. Za pojedine tvrđenje iz ček liste, koje se odnose na zadatke istraživanja, izračunat je i $\chi 2$ kako bi se utvrdilo da li su dobiveni rezultati statistički značajni.

Prije početka samog procesa igre neophodno je da se obezbjedi mjesto i akteri za igru. Kod predškolske djece najčešće u organizaciji same igre učestvuje vaspitač, posebno kada su u pitanju grupne igre. Mi smo nastojali da u ovim istraživanjem ispitamo koliko su djece predškolskog uzrasta u stanju da samostalno organizuju igru uz minimalnu pomoć vaspitača. Kako bi smo to ispitali posmatrali smo koliko djeca često sama predlažu igre i daju inicijativu za početak neke igre. Rezultati su predstavljeni u tablici 1. 
Tablica br.1 Sposobnost djece da organizuju igru

\begin{tabular}{|l|c|c|}
\hline & \multicolumn{2}{|c|}{ Broj odgovora } \\
\cline { 2 - 3 } & $\mathrm{f}$ & $\%$ \\
\hline Dijete predlaže i samostalno organizuje igru & 8 & 40 \\
\hline $\begin{array}{l}\text { Dijete predlaže igru ali organizuje igru uz pomoć druge djece } \\
\text { i vaspitača }\end{array}$ & 11 & 55 \\
\hline $\begin{array}{l}\text { Dijete ne predlaže niti se samostalno uključuje u organizaciju } \\
\text { igre }\end{array}$ & 1 & 5 \\
\hline
\end{tabular}

Iz tabele je vidljivo da je većina djece posmatrane u igri spremno da učestvuje u organizaciji igre, ali samo $40 \%$ djece je samostalno predlagala i organizovalo igru, dok je 55\% djece često davalo inicijativu za igru ali im je bila potrebna pomoć ostale djece ili vaspitača kako bi organizovali igru. Ostala djeca nisu davala inicijativu za igru a samo su se povremeno uključivali u pripreme i organizaciju igre i pri tome su slijedila upute ostale djece i vaspitača. Kako bi smo provjerili da li su dobiveni rezultati statistički značajni, izračunali smo hi-kvadrat test. Hi-kvadrat test računali smo na temelju opažanih i slučajnih frekvencija preme forumli:

$$
\chi^{2}=\Sigma(\mathrm{f} 0-\mathrm{ft}) 2 / \mathrm{ft}
$$

Tablica br. 1.1. Izračunavanje hi-kvadrat testa

\begin{tabular}{|c|c|c|c|}
\hline $\mathrm{OP}$ & OČ & $(\mathrm{OP}-\mathrm{OČ}) 2$ & (OP-OČ) $2 /$ OČ \\
\hline 8 & 6,66 & 1,642 & 0,269 \\
\hline 11 & 6,66 & 4,342 & 2,82 \\
\hline 1 & 6,66 & $-5,662$ & 4,81 \\
\hline & & \multicolumn{2}{|l|}{$\Sigma \chi 2=7,899$} \\
\hline
\end{tabular}

Dobivena vrijednost hi-kvadrata, na drugom stupnju slobode, značajno odstupa od granične vrijednosti hi-kvadrata na razini $0,05(5,991)$. Na osnovu toga zaključujemo da je dobiveni hi-kvadrat statistički značajan, odnosno da su prikazani rezultati statistički značajni, te da je potvrđena naša prva hipoteza.

Kako bi grupna dječija igra mogle da funkcioniše neophodno je da su djeca spremna da odigraju određenu ulogu u igri. Ponekad djeca samostalno biraju svoju ulogu, ali u grupnim igrama često moraju prihavatati da odigraju ulogu koju im dodjele druga djeca. Zbog toga smo ispitali spremnost djece da prihvate ulogu u igri koju im dodjeljuju druga djeca. Rezultati su prikazani u tablici 2 . 
Tablica br.2 Spremnost djece da prihvate ulogu u igri koju im dodjeljuju druga djeca

\begin{tabular}{|l|c|c|}
\hline & \multicolumn{2}{|l|}{ Broj odgovora } \\
\cline { 2 - 3 } & $\mathrm{f}$ & $\%$ \\
\hline $\begin{array}{l}\text { Dijete uvijek prihvata ulogu u igri koju mu dodjele druga } \\
\text { djeca }\end{array}$ & 12 & 60 \\
\hline $\begin{array}{l}\text { Dijete samo ponekad prihvata ulogu u igri koju mu dodjele } \\
\text { druga djeca }\end{array}$ & 5 & 25 \\
\hline $\begin{array}{l}\text { Dijete nikada ne prihvata ulogu u igri koju mu dodjele } \\
\text { druga djeca }\end{array}$ & 3 & 15 \\
\hline
\end{tabular}

Iz rezultata u tablici 2 vidimo da je većina djece spremna da prihvate ulogu u igri koju im dodjele ostala djeca. Prema ovim rezultatima možemo smatrati da je veliki broj djece spreman na suradnju kada je u pitanju igra. Za dobivene rezultate možemo reći da su statistički značajni, te možemo zaključiti da su djeca predškolskog uzrasta spremna na suradnju u igri i prihvatanje uloga koje im dodjeljuju druga djeca.

Prihvatanje i poštivanje pravila u igri je jedan od osnovnih uvjeta koji mora biti ispunjen kako bi se igre sa pravilima mogle realizovati. Djeca tokom perioda odrastanja posmatraju odrasle i kroz igru ih oponašaju, te tako uče i određena pravila ponašanja ali $\mathrm{u}$ tim se igrama ne moraju uvijek ponašati po pravilima. Međutim, kada su u pitanju igre sa pravilima tu je potrebno strogo poštivanje pravila. Prilikom posmatranja djece u igara sa pravilima, u igru je bio uključen vaspitač nekada kao osoba koja je usmjeravala igru i nametala pravila a nekada kao igrač. Tokom tih igara nastojali smo ispitati koliko su djeca spremna da učestvuju u zajedničkoj igri i da poštoju pravila igre. Rezultati su prikazani u tablici 3.

Tablica br.3 Poštivanje pravila u igri

\begin{tabular}{|l|c|c|}
\hline & \multicolumn{2}{|c|}{ Broj odgovora } \\
\cline { 2 - 3 } & $\mathrm{f}$ & $\%$ \\
\hline Dijete uvijek poštuje pravila igre & 13 & 65 \\
\hline $\begin{array}{l}\text { Dijete se trudi poštovati pravila igre ali ponekad odstupa od } \\
\text { postavljenih pravila }\end{array}$ & 5 & 25 \\
\hline $\begin{array}{l}\text { Dijete ne poštuje pravila igre i pokušava igru prilagoditi } \\
\text { svojim pravilima }\end{array}$ & 2 & 10 \\
\hline
\end{tabular}

Ono što je primjećeno tokom igranja igara sa pravilima je da se predškolska djeca jako trude da ispoštuju pravila igre i da najbolje što mogu odigraju igru koja im je dodjeljena. Većina djece (65\%) uspjevala je tokom ovih igara da u igri učestvuje do kraja ne odstupajući od pravila igre, dok je mali broj djece povremenio odstupao od pravila 
igre. Za dobivene rezultate možemo reći da su statistički značajni i da ukazuju na to da su djeca predškolskog uzrasta spremna da poštuju pravila igre.

\section{PREPORUKE I ZAKLJUČCI}

Djetinstvo je nesumnjivo najznačajniji i najbogatiji period, u smislu razvoja i obogaćenja ličnosti djeteta, u životu svakog pojedinca. Ono što čovjek doživi, osjeti i prođe u djetinstvi ostavlja dubok trag i značaj za cijeli život svakog pojedinca i određuje kako će se svaka individua dalje razvijati i ukolpiti u život i svijet odraslih. Socijalizacija djece predškolskog uzrasta, ponajprije kroz igru, je značajno pitanje kojim se mora baviti jer je to jedan od prvih načina na koje dijete stupa u svoje socijalne kontakte sa svojim vršnjačima. Predškolsko dijete kroz te kontakte i igru ulazi u svijet odrasli i priprema se za odrastanje. Kroz igru dijete uči kako da se ponaša prema drugima i kako se drugi mogu ponašati prema njemu, kakve vrste kontakata moze doživjeti, na koji način ti kontakti mogu da završe i sl. Na osnovu dobivenih rezultata u ovom istraživanju mogu se izvesti neki zaključci i preporuke:

- Djecu treba poticati na igru, te ih ohrabrivati i naučiti da sami preuzimaju inicijativu i organizuju igru. Kroz igru s ostalom djecim predškolsko dijete razvije svoje prve i najranije socijalne odnose od kojih će mnogo zavisiti njegovi socijalni kontakti u budućnosti. Zbog toga je neophodno i poželjno djetetu omogućiti igru s drugom djecom.

- Djecu treba postupno učiti kako da budu spremni na prihvatanje uloga koje ne biraju samo oni, nego koje im dodjeljuju druga djeca, ali kako dijete ne bi steklo dojam da uvijek treba da se potčinjava drugima, potrebno je nekada dozvoliti i da se dijete bori za ulogu koju želi. Zbog toga je poželjno i neophodno u igru uključiti odgajatelje i roditelje kako bi učestvovali u pripremi i organizaciji dječijih igara kroz koje djeca uče nove uloge i način na koji treba da prihvataju različite pozicije u igri.

- Kada su djeca već spremna za igre sa pravilima neophodno ih je postupno pripremati za poštivanje paravila u igri. Dijeca u svim kulutrama već od najranijeg djetinstva, posmatrajući različite uloge i kontakte odraslih, uči da poštoje određena pravila kojih se mora pridržavati. Vremenom djeca takvo ponašanje prenose u igru. Učeći se da poštuju pravila u igri, djeca razvijaju svoje socijalne vještine koje im kasnije omogućavaju da uspješno funkcionišu i različitim ulogama i u različitim situacijama.

\section{LITERATURA}

1. BERK, L. (2007), Psihologija cjeloživotnog razvoja, Zagreb: NAKLADA SLAP

2. ELJKONJIN, D.B. (1978), Psihologija dječije igre, Beograd: Zavod za udžbenike i nastavna sredstva

3. FANUKO, N. (1997), Sociologija, Zagreb: Profil 
4. GRUPA AUTORA (1982), Proces socijalizacije kod djece, Beograd: Zavod za udžbenike i nastavna sredstva

5. KAMENOV, E., (1997), Model osnova programa vaspitno-obrazovnog rada sa predškolskom decom, Novi Sad

6. MITROVIĆ, D. (1981), Predškolska pedagogija, Sarajevo: Zavod za udžbenike i nastavna sredstva

7. SUZIĆ, N. (2006), Uvod u predškolsku pedagogiju i metodiku, Banja Luka: XBS

8. ŠOLJAN, N.N. (1976), Obrazovna tehnologija, Zagreb: Školska knjiga

9. VIGOTSKI, L. S. (1996), Pitanja teorije i istorije psihologije, Beograd: Zavod za udžbenike i nastavna sredstva

\section{IMPORTANCE OF THE GAME IN SOCIALIZATION OF PRESCHOOL- CHILDREN}

\section{SUMMARY}

Game has a huge importance in a process of socialization the children. It is almost the most important factor in this process and I decided to pay attention on children games in this research. We will theoretical and in detail try to show the importance of the game in socialization pre-school children and how the game can contribute to the quality and more healtheir socialization the pre-school children.

The general aim of this research study is to examine the role of play in the socialization of children of preschool age. This research aims to discover how children are preschoolers able to self-organize the game, to accept the theme of the game and the stakes involved in their assigned other children to bring their ideas to the ideas of their peers and to actively participate in the game.

The study involved 20 children of preschool age. Results from this study indicate the importance of play in a huge sodijalizaciji preschool children.

Keywords: socialization, preschool children, game. 